\title{
Desulfurococcus fermentans sp. nov., a novel hyperthermophilic archaeon from a Kamchatka hot spring, and emended description of the genus Desulfurococcus
}

Correspondence

E. A. Bonch-Osmolovskaya Ibo@mail.ru

\author{
A. A. Perevalova, ${ }^{1}$ V. A. Svetlichny, ${ }^{2}$ I. V. Kublanov, ${ }^{1}$ \\ N. A. Chernyh, ${ }^{1}$ N. A. Kostrikina, ${ }^{1}$ T. P. Tourova, ${ }^{1}$ \\ B. B. Kuznetsov ${ }^{3}$ and E. A. Bonch-Osmolovskaya ${ }^{1}$ \\ ${ }^{1}$ Institute of Microbiology, Russian Academy of Sciences, Prospect 60-letiya Oktyabrya 7/2, \\ Moscow 117312, Russia \\ ${ }^{2}$ Lehrstuhl für Mikrobiologie, Universität Bayreuth, D-95440 Bayreuth, Germany \\ ${ }^{3}$ Bioengineering Center, Russian Academy of Sciences, Prospect 60-letiya Oktyabrya 7/1, \\ Moscow 117312, Russia
}

An obligately anaerobic, hyperthermophilic, organoheterotrophic archaeon, strain Z-1312 ${ }^{\top}$, was isolated from a freshwater hot spring of the Uzon caldera (Kamchatka Peninsula, Russia). The cells were regular cocci, 1-4 $\mu \mathrm{m}$ in diameter, with one long flagellum. The cell envelope was composed of a globular layer attached to the cytoplasmic membrane. The temperature range for growth was $63-89^{\circ} \mathrm{C}$, with an optimum between 80 and $82^{\circ} \mathrm{C}$. The $\mathrm{pH}$ range for growth at $80^{\circ} \mathrm{C}$ was $4 \cdot 8-6 \cdot 8$, with an optimum at $\mathrm{pH} 6 \cdot 0$. Strain $\mathrm{Z}-1312^{\top}$ grew by hydrolysis and/or fermentation of a wide range of polymeric and monomeric substrates, including agarose, amygdalin, arabinose, arbutin, casein hydrolysate, cellulose (filter paper, microcrystalline cellulose, carboxymethyl cellulose), dextran, dulcitol, fructose, lactose, laminarin, lichenan, maltose, pectin, peptone, ribose, starch and sucrose. No growth was detected on glucose, xylose, mannitol or sorbitol. Growth products when sucrose or starch were used as the substrate were acetate, $\mathrm{H}_{2}$ and $\mathrm{CO}_{2}$. Elemental sulfur, thiosulfate and nitrate added as potential electron acceptors for anaerobic respiration did not stimulate growth when tested with starch as the substrate. $\mathrm{H}_{2}$ at $100 \%$ in the gas phase did not inhibit growth on starch or peptone. The $G+C$ content of the DNA was $42.5 \mathrm{~mol} \%$. 16S rRNA gene sequence analysis placed the isolated strain $Z-1312^{\top}$ as a member of the genus Desulfurococcus, where it represented a novel species, for which the name Desulfurococcus fermentans sp. nov. (type strain Z-1312 ${ }^{\top}=\mathrm{DSM} 16532^{\top}=\mathrm{VKM} \mathrm{V}-2316^{\top}$ ) is proposed.
Anaerobic, hyperthermophilic prokaryotes with fermentative metabolism have been identified in both archaeal kingdoms, Euryarchaeota and Crenarchaeota (Blöchl et al., 1995; Stetter, 1996; Huber et al., 2000). Usually, these organisms grow on complex media with proteins or peptides as the energy substrates, producing volatile fatty acids, $\mathrm{CO}_{2}$ and $\mathrm{H}_{2}$ as fermentation products. Molecular hydrogen often inhibits growth of fermentative archaea; elimination of $\mathrm{H}_{2}$ by reduction of elemental sulfur to $\mathrm{H}_{2} \mathrm{~S}$, by flushing the cultures with an inert gas (Fiala \& Stetter, 1986) or by cultivation in co-cultures with $\mathrm{H}_{2}$-consuming

Published online ahead of print on 4 February 2005 as DOI 10.1099/ ijs.0.63378-0.

The GenBank/EMBL/DDBJ accession number for the 16S rRNA gene sequence of Desulfurococcus fermentans Z $-1312^{\top}$ is AY264344. methanogens (Bonch-Osmolovskaya \& Stetter, 1991) supports the growth of fermentative archaea. Thus, growth of most fermentative archaea in closed vessels is either obligately dependent on elemental sulfur or stimulated by its presence. An exception is the fermentation observed with two representatives of the Crenarchaeota, Sulfophobococcus zilligii (Hensel et al., 1997) and Thermosphaera aggregans (Huber et al., 1998), which do not require elemental sulfur and are inhibited by its presence. All members of the genus Desulfurococcus reported to date (Zillig et al., 1982; BonchOsmolovskaya et al., 1988) grow exclusively or preferably on peptides, concomitantly reducing elemental sulfur to $\mathrm{H}_{2} \mathrm{~S}$. Their growth on peptides is stimulated significantly by the presence of elemental sulfur and inhibited by $\mathrm{H}_{2}$ (Slobodkin \& Bonch-Osmolovskaya, 1994). Desulfurococcus amylolyticus (Bonch-Osmolovskaya et al., 1988; Tourova 
et al., 2000) can grow on starch, glycogen or pectin, but its growth on these substrates is much weaker in comparison with that on peptides and also depends on the presence of $S^{0}$. Here, we describe a strain representing a novel hyperthermophilic species of the genus Desulfurococcus, Desulfurococcus fermentans, isolated from a Kamchatka hot spring. The organism grows by fermentation of diverse carbohydrates, including cellulose, does not require the presence of elemental sulfur and is not inhibited by $\mathrm{H}_{2}$. To our knowledge, this is the first report on an archaeon that is able to grow on cellulosic substrates.

Samples of water and mud from a freshwater hot spring of the Uzon caldera (Kamchatka Peninsula, Russia) were used for inoculation of anaerobically prepared basal medium of the following composition ( $\mathrm{mg} \mathrm{l}^{-1}$ unless indicated): $\mathrm{KCl}, 330 ; \mathrm{NH}_{4} \mathrm{Cl}, 330 ; \mathrm{KH}_{2} \mathrm{PO}_{4}, 330 ; \mathrm{MgCl}_{2} .6 \mathrm{H}_{2} \mathrm{O}, 330$; $\mathrm{CaCl}_{2} .2 \mathrm{H}_{2} \mathrm{O}, 330 ; \mathrm{Na}_{2} \mathrm{~S} .9 \mathrm{H}_{2} \mathrm{O}, 500$; starch, 5000; yeast extract (Difco), 200; resazurin, 1; trace element solution (Pfennig \& Lippert, 1965), $1 \mathrm{ml} \mathrm{l}^{-1}$; vitamin solution (Wolin et al., 1963), $1 \mathrm{ml} \mathrm{l}^{-1}$; pH 6.5 (adjusted with $\mathrm{H}_{2} \mathrm{SO}_{4}$ ). The medium was prepared anaerobically under an atmosphere of $80 \% \mathrm{~N}_{2}+20 \% \mathrm{CO}_{2}$ and dispensed into $15 \mathrm{ml}$ Hungate tubes with butyl rubber stoppers, leaving $5 \mathrm{ml}$ as the headspace.

After 3-5 days incubation at $85^{\circ} \mathrm{C}$, an organism with regular coccoid cells, often forming sarcina-like aggregates, was enriched from the Uzon caldera sample. In pure culture obtained by serial dilutions of the initial enrichment, the cells were present only as single coccoid cells. The new isolate was designated strain $\mathrm{Z}-1312^{\mathrm{T}}$.

Cells of strain $\mathrm{Z}-1312^{\mathrm{T}}$ were regular cocci, $1-4 \mu \mathrm{m}$ in diameter (Fig. 1a). On electron micrographs of whole cells, a long single flagellum is present. Thin sections (BonchOsmolovskaya et al., 1990) revealed a cell-wall structure consisting of a cellular membrane covered by one layer of subunits (Fig. 1b). Strain Z-1312 ${ }^{\mathrm{T}}$ was an obligate anaerobe, since no growth was observed under oxic conditions as well as under anoxic conditions when the medium was not prereduced by the addition of sodium sulfide. The organism was a hyperthermophile, growing in the temperature range $63-89^{\circ} \mathrm{C}$ with an optimum at $80-82^{\circ} \mathrm{C}$. Strain $\mathrm{Z}-1312^{\mathrm{T}}$ grew over a $\mathrm{pH}$ range of $4 \cdot 8-6 \cdot 8$, with an optimum at $\mathrm{pH} 6 \cdot 0$.

Strain Z-1312 ${ }^{\mathrm{T}}$ grew by fermentation of starch $\left(5 \mathrm{~g} \mathrm{l}^{-1}\right)$ or cellulose $\left(2 \mathrm{~g} \mathrm{l}^{-1}\right)$ (filter paper, microcrystalline cellulose, carboxymethyl cellulose) as well as of a wide range of monomeric and polymeric substrates $\left(2 \mathrm{~g} \mathrm{l}^{-1}\right)$, including agarose, arabinose, arbutin, casein hydrolysate, dulcitol, pectin, peptone, sucrose and yeast extract, with a final cell yield of $2 \cdot 5-5 \cdot 0 \times 10^{7}$ cells $\mathrm{ml}^{-1}$. Weaker growth resulting in a cell yield around or below $2 \cdot 0 \times 10^{7}$ cells ml $^{-1}$ was observed on amygdalin, dextran, fructose, lactose, laminarin, lichenan, maltose and ribose. No growth was detected on glucose, xylose, mannitol or sorbitol. Growth curves of strain $\mathrm{Z}-1312^{\mathrm{T}}$ on media with starch and microcrystalline cellulose are shown in Fig. 2. The final cell yield on starch

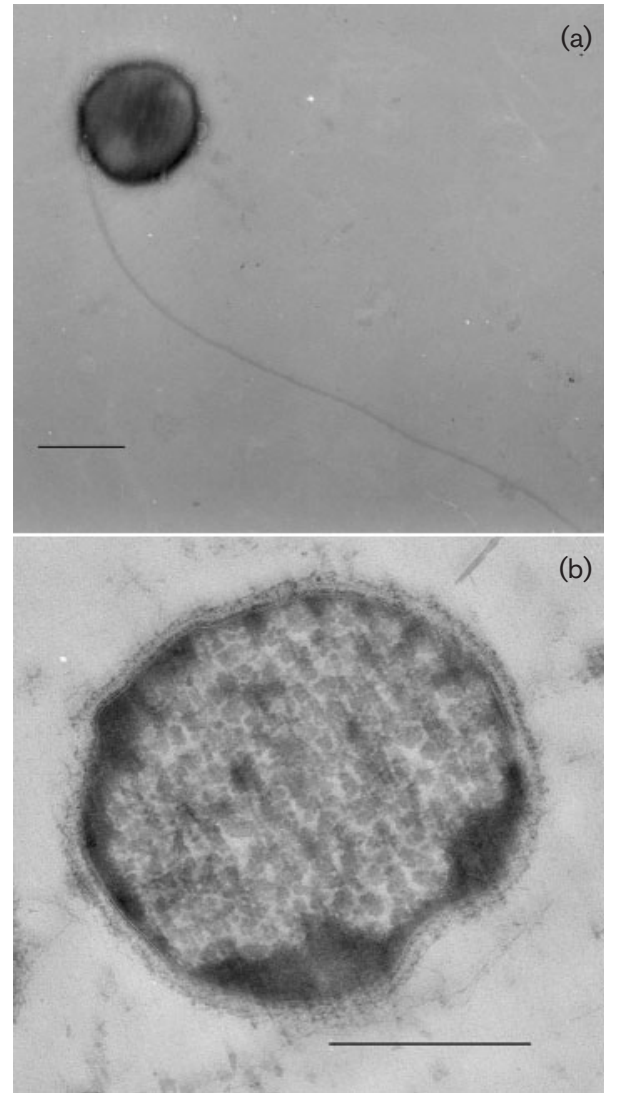

Fig. 1. Electron micrographs of cells of strain $Z-1312^{\top}$. (a) Negatively stained whole cell showing a single flagellum. (b) Thin section. Bars, $0.5 \mu \mathrm{m}$.

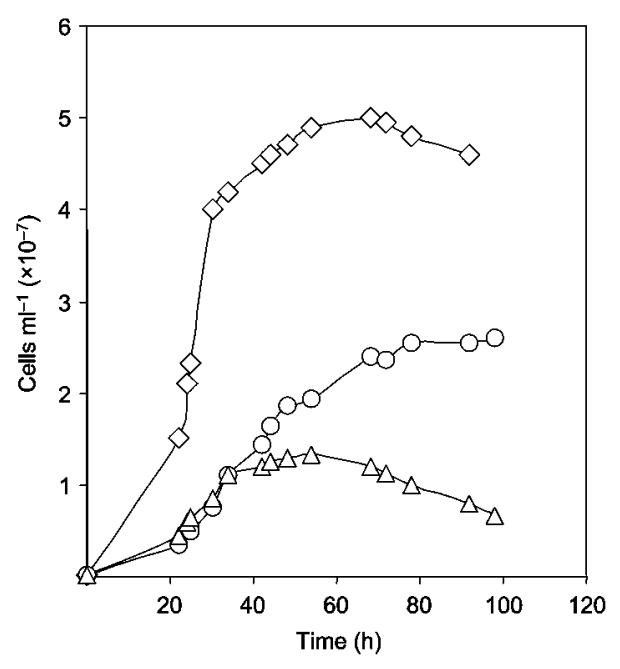

Fig. 2. Growth of strain $Z-1312^{\top}$ on media containing $0.2 \mathrm{~g}$ yeast extract $\mathrm{I}^{-1}$ alone $(\triangle)$ or additionally supplemented with $5 \mathrm{~g}$ starch $\mathrm{I}^{-1}(\diamond)$ or $5 \mathrm{~g}$ microcrystalline cellulose $\mathrm{I}^{-1}(\bigcirc)$. The incubation temperature was $82^{\circ} \mathrm{C}$ and the $\mathrm{pH}$ of the media was $6 \cdot 0$. 
was $5 \times 10^{7}$ cells $\mathrm{ml}^{-1}$, while the doubling time was $6 \cdot 3 \mathrm{~h}$. On microcrystalline cellulose, the final cell yield was around $2.5 \times 10^{7}$ cells $\mathrm{ml}^{-1}$ and the doubling time was $10 \cdot 7 \mathrm{~h}$. The only growth products (Bonch-Osmolovskaya \& Miroshnichenko, 1994) detected during growth on media with starch or sucrose were acetate, $\mathrm{H}_{2}$ and $\mathrm{CO}_{2}$. Growth on cellulosic substrates, peptone, starch and sucrose was found to be stimulated by yeast extract (optimum concentration $200 \mathrm{mg} \mathrm{l}^{-1}$ ). The ability of strain $\mathrm{Z}-1312^{\mathrm{T}}$ to use elemental sulfur as an electron acceptor was tested in cultures growing on starch and peptone. Although sulfur was reduced to hydrogen sulfide, no effect of the presence of sulfur on the cell yield was observed. Thiosulfate, sulfate and nitrate were not reduced and did not influence growth on starch or peptone. $\mathrm{H}_{2}(100 \%$ in the gas phase) did not inhibit growth of strain Z-1312 $2^{\mathrm{T}}$ on starch or peptone.

The $\mathrm{G}+\mathrm{C}$ content of the DNA of strain $\mathrm{Z}-1312^{\mathrm{T}}$ was determined by the denaturation method (Owen \& Lapage, 1976) as $42.5 \mathrm{~mol} \%$. Analysis of partial $16 \mathrm{~S}$ rRNA gene sequences of strain $\mathrm{Z}-1312^{\mathrm{T}}$ (1378 nucleotides) was done as described previously (Sanger et al., 1977) using 5' -AGAGTTTGATCCTGGCTCAG-3' as the forward primer and $5^{\prime}$-TACGGTTACCTTGTTACGACTT- $3^{\prime}$ as the reverse primer (Lane, 1991). This sequence has a high G + C content $(65 \cdot 0 \%)$, as observed previously for the $16 \mathrm{~S}$ rRNA genes of other thermophilic prokaryotic organisms. Primary analysis of $16 \mathrm{~S}$ rRNA gene nucleotide sequence similarity of the new isolate was carried out using the BLASTA server (http://www.ncbi.nlm.nih.gov/blast). The sequences were aligned against the corresponding $16 \mathrm{~S}$ rRNA gene sequences of related organisms using the CLUSTAL program (Thompson et al., 1994). Positions that had not been sequenced in one or more reference organisms were omitted and a total of 1193 nucleotides were used in the analysis. The phylogenetic tree rooted by the outgroup Methanococcus vannielii was constructed by the neighbour-joining method with bootstrap analysis of 100 trees using the programs of the TREECON package (Van de Peer \& De Wachter, 1994). This analysis revealed that strain $\mathrm{Z}-1312^{\mathrm{T}}$ was a member of the family Desulfurococcaceae (Burggraf et al., 1997) (kingdom Crenarchaeota, domain Archaea). Additional sequence alignments and phylogenetic analysis performed with members of this family revealed that strain $\mathrm{Z}-1312^{\mathrm{T}}$ was closely related to the species of the genus Desulfurococcus (95.5-96.4\% sequence similarity). In the phylogenetic tree (Fig. 3), strain Z-1312 ${ }^{\mathrm{T}}$ formed a single cluster with Desulfurococcus species with a high level of bootstrap probability of this branching point $(96 \%)$.

The genus Desulfurococcus (Zillig et al., 1982) at present consists of three species with validly published names: Desulfurococcus mucosus, the type species of the genus, Desulfurococcus mobilis (Zillig et al., 1982) and D. amylolyticus (Bonch-Osmolovskaya et al., 1988; Tourova et al., 2000). Nucleotide sequences of the 16S rRNA gene have been obtained only for the last two species. Representatives of these species could be detected by specific oligonucleotide probes (Perevalova et al., 2003). The affiliation of isolate $\mathrm{Z}-1312^{\mathrm{T}}$ to the genus Desulfurococcus is in good agreement with common phenotypic features that exist between strain $\mathrm{Z}-1312^{\mathrm{T}}$ and other representatives of the genus Desulfurococcus (Table 1). However, although it shows the same cell morphology and growth characteristics, strain $\mathrm{Z}-1312^{\mathrm{T}}$ differs significantly in growth substrates and its relation to elemental sulfur and $\mathrm{H}_{2}$. In contrast to other Desulfurococcus species, which prefer proteinaceous substrates, it grows well on different monomeric and polymeric carbohydrates. Elemental sulfur is not required for growth, which is in agreement with the lack of an inhibitory effect of $\mathrm{H}_{2}$ on growth.

Peptides are the common substrates of anaerobic, organotrophic, hyperthermophilic archaea, while carbohydrates are metabolized by a limited number of hyperthermophilic archaeal species (Schönheit \& Schäfer, 1995). Pyrococcus furiosus can ferment maltose and cellobiose (Fiala \& Stetter, 1986; Schäfer \& Schönheit, 1992), Pyrococcus woesei, D. amylolyticus, Thermococcus stetteri and Acidilobus aceticus were able to grow fermentatively on starch (Zillig et al., 1987; Bonch-Osmolovskaya et al., 1988; Miroshnichenko et al., 1989; Prokofeva et al., 2000) and Pyrococcus glycovorans was able to grow fermentatively on glucose, cellobiose and starch (Barbier et al., 1999). The range of growth

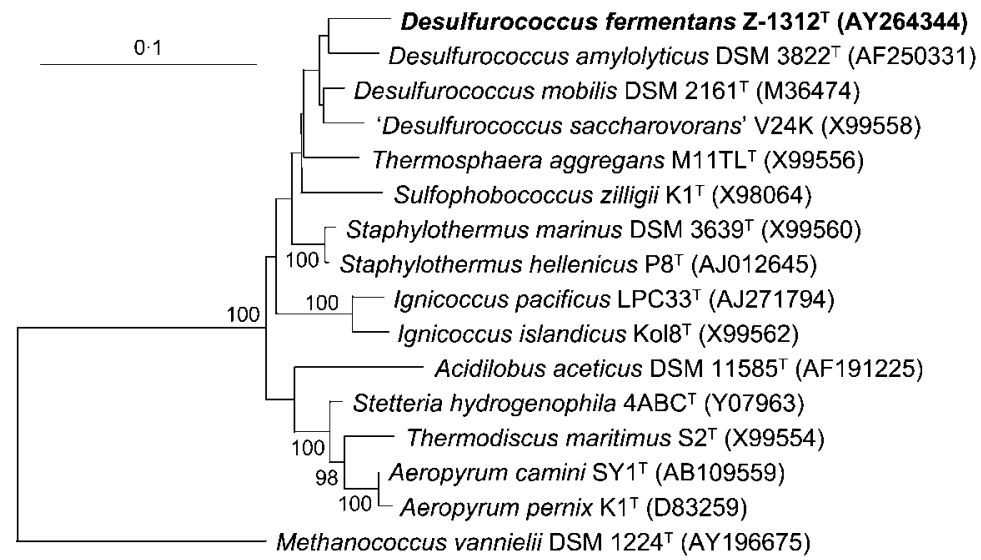

Fig. 3. Phylogenetic tree generated by the neighbour-joining method on the basis of 16S rRNA gene sequences showing the position of Desulfurococcus fermentans sp. nov. Z-1312 ${ }^{\top}$ among members of the family Desulfurococcaceae. Bootstrap values (of 100 replications) are shown at branch points; values greater than 95 were considered significant. Bar, 10 nucleotides substitutions per 100 nucleotides. 
Table 1. Characteristics of strain $Z-1312^{\top}$ and species of the genus Desulfurococcus

\begin{tabular}{|lcccc|}
\hline Characteristic & D. mucosus & D. mobilis & D. amylolyticus & Z-1312 $^{\text {T }}$ \\
\hline Shape and size of cells & Cocci & Cocci & Irregular cocci & Regular cocci, $1-4 \mu \mathrm{m}$ \\
Flagellation & No flagella & One flagellum & No flagella & One flagellum \\
Growth temperature $\left({ }^{\circ} \mathrm{C}\right)$ (min./opt./max.) & $\mathrm{ND} / 85 / \mathrm{ND}$ & $\mathrm{ND} / 85 / \mathrm{ND}$ & $68 / 90-92 / 97$ & $63 / 80-82 / 89$ \\
Growth $\mathrm{pH}($ min./opt./max.) & $4 \cdot 5 / 6 \cdot 0 / 7 \cdot 0$ & $4 \cdot 5 / 6 \cdot 0 / 7 \cdot 0$ & $5 \cdot 7 / 6 \cdot 4 / 7 \cdot 5$ & $4 \cdot 8 / 6 \cdot 0 / 6 \cdot 8$ \\
Growth substrates & Peptides & Peptides & Peptides, starch & Peptides, monosaccharides, \\
& & & polysaccharides including cellulose \\
Influence of sulfur on growth & Stimulating & Stimulating & Stimulating & No effect \\
Influence of hydrogen on growth & Inhibiting* & ND & Inhibiting* & No effect \\
G + C content of DNA (mol\%) & $51 \cdot 3$ & $50 \cdot 8$ & $41 \cdot 2$ & $42 \cdot 5$ \\
\end{tabular}

ND, No data.

${ }^{\star}$ Data from Slobodkin \& Bonch-Osmolovskaya (1994).

substrates of strain $\mathrm{Z}-1312^{\mathrm{T}}$ is much wider than that of other hyperthermophilic archaea, including cellulose and other mono-, di- and polysaccharides. In this capacity it resembles 'Desulfurococcus saccharovorans' (Stetter, 1986); however, the name of this species was never validly published.

A unique feature of the new isolate is its ability to grow on cellulosic substrates (microcrystalline cellulose, carboxymethyl cellulose, filter paper). To our knowledge, strain Z$1312^{\mathrm{T}}$ is the first hyperthermophilic archaeon able to grow on such substrates. So far, genes for endoglucanase that could be involved in cellulose degradation have been found in several hyperthermophilic archaea. Endoglucanase genes detected in the genomes of $P$. furiosus, Pyrococcus horikoshii and Sulfolobus solfataricus have been cloned and expressed in Escherichia coli (Bauer et al., 1999; Limauro et al., 2001; Ando et al., 2002). However, growth of these microorganisms on cellulosic substrates has never been reported. Taking into consideration both phenotypic and genosystematic differentiating features between strain Z-1312 and other Desulfurococcus species, we propose that it represents a novel species, Desulfurococcus fermentans sp. nov. The description of this novel species necessitates the emendation of the description of the genus.

\section{Description of Desulfurococcus fermentans sp. nov.}

Desulfurococcus fermentans (fer.men'tans. L. part. adj. fermentans fermenting).

Cells are cocci, $1-4 \mu \mathrm{m}$ in diameter, with one polar flagellum. Obligate anaerobe. Temperature growth range from 63 to $89^{\circ} \mathrm{C}$, with optimum at $82^{\circ} \mathrm{C}$. pH growth range from $4 \cdot 8$ to $6 \cdot 8$, with optimum at $\mathrm{pH} 6 \cdot 0$. Obligate chemoorganoheterotroph; obtains energy by fermentation of arabinose, agarose, amygdalin, arbutin, casein hydrolysate, cellulose, dextran, dulcitol, fructose, lactose, laminarin, lichenan, maltose, pectin, peptone, ribose, starch and sucrose. No growth is observed on glucose, mannitol, sorbitol or xylose. Fermentation products detected are acetate, $\mathrm{H}_{2}$ and $\mathrm{CO}_{2}$. Growth is not inhibited by $100 \%$ $\mathrm{H}_{2}$. Elemental sulfur, sulfate, thiosulfate and nitrate do not stimulate growth and are not used as electron acceptors. The $\mathrm{G}+\mathrm{C}$ content of DNA of the type strain is $42.5 \mathrm{~mol} \%$.

The type strain, strain $\mathrm{Z}-1312^{\mathrm{T}}\left(=\mathrm{DSM} 16532^{\mathrm{T}}=\mathrm{VKM}\right.$ $\mathrm{V}-2316^{\mathrm{T}}$ ), was isolated from a hot spring of Uzon caldera, Kamchatka peninsula, Russia. The GenBank/EMBL/DDBJ accession number of the 16S rRNA gene sequence of the type strain is AY264344.

\section{Emended description of genus Desulfurococcus Zillig and Stetter 1983}

Desulfurococcus (De.sul.fu.ro.coc'cus. N.L. pref. de from; L. n. sulfur sulfur; Gr. n. coccus berry; N.L. masc. n. Desulfurococcus the sulfur-reducing coccus).

Archaea of the kingdom Crenarchaeota. Cells are regular or irregular cocci, with or without flagella, with a cell envelope of globular structure. Hyperthermophiles with optimum growth temperature of $80-90^{\circ} \mathrm{C}$. Neutrophiles or moderate acidophiles with optimum $\mathrm{pH}$ for growth of $6 \cdot 0-6 \cdot 5$. Obligate anaerobes. Organotrophs utilizing a wide range of organic substrates: peptides and monomeric and polymeric carbohydrates. Fermentative type of metabolism. Growth of representatives of some species is inhibited by molecular hydrogen and stimulated by the presence of elemental sulfur. The $\mathrm{G}+\mathrm{C}$ content of the DNA is 41$51 \mathrm{~mol} \%$. Reported species inhabit terrestrial hot springs. The type species is Desulfurococcus mucosus Zillig and Stetter 1983 (type strain ATCC $35584^{\mathrm{T}}=$ DSM $2162^{\mathrm{T}}=$ JCM $\left.9187^{\mathrm{T}}\right)$.

\section{Acknowledgements}

This work was supported by RFBR grants number 02-04-48112 and 03-04-49000, by INTAS grant $01-250$ and by the Programs of the Russian Academy of Sciences 'Molecular and Cell Biology', 'Biodiversity' and 'Evolution of Biosphere'. 


\section{References}

Ando, S., Ishida, H., Kosugi, Y. \& Ishikawa, K. (2002). Hyperthermostable endoglucanase from Pyrococcus horikoshii. Appl Environ Microbiol 68, 430-433.

Barbier, G., Godfroy, A., Meunier, J.-R., Querellou, J., Cambon, M.-A., Lesongeur, F., Grimont, P. A. D. \& Raguenes, G. (1999). Pyrococcus glycovorans sp. nov., a hyperthermophilic archaeon isolated from the East Pacific Rise. Int J Syst Bacteriol 49, 1829-1837.

Bauer, M. W., Driskill, L. E., Callen, W., Snead, M. A., Mathur, E. J. \& Kelly, R. M. (1999). An endoglucanase, EglA, from the hyperthermophilic archaeon Pyrococcus furiosus hydrolyzes $\beta-1,4$ bonds in mixed-linkage $(1 \rightarrow 3),(1 \rightarrow 4)-\beta$-D-glucans and cellulose. $J$ Bacteriol 181, 284-290.

Blöchl, E., Burggraf, S., Fiala, G. \& 7 other authors (1995). Isolation, taxonomy and phylogeny of hyperthermophilic microorganisms. World J Microbiol Biotechnol 11, 9-16.

Bonch-Osmolovskaya, E. A. \& Miroshnichenko, M. L. (1994). The influence of molecular hydrogen and elemental sulfur on the metabolism extremely thermophilic archaea of genus Thermococcus. Microbiology (English translation of Mikrobiologiia) 63, 433-437.

Bonch-Osmolovskaya, E. A. \& Stetter, K. O. (1991). Interspecies hydrogen transfer in cocultures of thermophilic archaea. Syst Appl Microbiol 14, 205-208.

Bonch-Osmolovskaya, E. A., Slesarev, A. I., Miroshnichenko, M. L., Svetlichnaya, T. P. \& Alekseev, V. A. (1988). Characterization of Desulfurococcus amylolyticus $\mathrm{n}$. sp. - a novel extremely thermophilic archaebacterium isolated from Kamchatka and Kurils hot springs. Microbiology (English translation of Mikrobiologiia) 57, 94-101.

Bonch-Osmolovskaya, E. A., Sokolova, T. G., Kostrikina, N. A. \& Zavarzin, G. A. (1990). Desulfurella acetivorans gen. nov. and sp. nov. - a new thermophilic sulfur-reducing eubacterium. Arch Microbiol 153, 151-155.

Burggraf, S., Huber, H. \& Stetter, K. O. (1997). Reclassification of the crenarchaal orders and families in accordance with 16S rRNA sequence data. Int J Syst Bacteriol 47, 657-660.

Fiala, G. \& Stetter, K. O. (1986). Pyrococcus furiosus sp. nov. represents a novel genus of marine heterotrophic archaebacteria growing optimally at $100^{\circ} \mathrm{C}$. Arch Microbiol 145, 56-61.

Hensel, R., Matussek, K., Michalke, K., Tacke, L., Tindall, B. J., Kohlhoff, M., Siebers, B. \& Dielenschneider, J. (1997). Sulfophobococcus zilligii gen. nov., spec. nov., a novel hyperthermophilic archaeum isolated from hot alkaline springs of Iceland. Syst Appl Microbiol 20, 102-110.

Huber, R., Dyba, D., Huber, H., Burggraf, S. \& Rachel, R. (1998). Sulfur-inhibited Thermosphaera aggregans sp. nov., a new genus of hyperthemophilic archaea isolated after its prediction from environmentally derived 16S rRNA sequences. Int J Syst Bacteriol 48, 31-38.

Huber, R., Huber, H. \& Stetter, K. O. (2000). Towards the ecology of hyperthermophiles: biotopes, new isolation strategies and new metabolic properties. FEMS Microbiol Rev 24, 615-623.

Lane, D. J. (1991). 16S/23S rRNA sequencing. In Nucleic Acid Techniques in Bacterial Systematics, pp. 115-147. Edited by E. Stackebrandt \& M. Goodfellow. New York: Wiley.

Limauro, D., Cannio, R., Fiorentino, G., Rossi, M. \& Bartolucci, S. (2001). Identification and molecular characterization of an endoglucanase gene, celS, from the extremely thermophilic archaeon Sulfolobus solfataricus. Extremophiles 5, 213-219.

Miroshnichenko, M. L., Bonch-Osmolovskaya, E. A., Neuner, A., Kostrikina, N. A., Chernyh, N. A. \& Alekseev, V. A. (1989). Thermococcus stetteri sp. nov., a new extremely thermophilic marine sulfur-metabolizing Archaebacterium. Syst Appl Microbiol 12, 257-262.

Owen, R. J. \& Lapage, S. P. (1976). The thermal denaturation of partly purified bacterial deoxyribonucleic acid and its taxonomic applications. J Appl Bacteriol 41, 335-340.

Perevalova, A. A., Lebedinsky, A. A., Bonch-Osmolovskaya, E. A. \& Chernyh, N. A. (2003). Detection of hyperthermophilic archaea of the genus Desulfurococcus by hybridization with oligonucleotide probes. Microbiology (English translation of Mikrobiologiia) 72, 383-389.

Pfennig, N. \& Lippert, K. D. (1965). Uber das Vitamin $B_{12}$-Bedurfnis photographer Schweefelbakterien. Arch Mikrobiol 55, 245-246 (in German).

Prokofeva, M. I., Miroshnichenko, M. L., Kostrikina, N. A., Chernyh, N. A., Kuznetsov, B. B., Tourova, T. P. \& Bonch-Osmolovskaya, E. A. (2000). Acidilobus aceticus gen. nov., sp. nov., a novel anaerobic thermoacidophilic archaeon from continental hot vents in Kamchatka. Int J Syst Evol Microbiol 50, 2001-2008.

Sanger, F., Nicklen, S. \& Coulson, A. R. (1977). DNA sequencing with chain-terminating inhibitors. Proc Natl Acad Sci U S A 74, 5463-5467.

Schäfer, T. \& Schönheit, P. (1992). Maltose fermentation to acetate, $\mathrm{CO}_{2}$ and $\mathrm{H}_{2}$ in the anaerobic hyperthermophilic archaeon Pyrococcus furiosus: evidence for the operation of a novel sugar fermentation pathway. Arch Microbiol 158, 188-202.

Schönheit, P. \& Schäfer, T. (1995). Metabolism of hyperthermophiles. World J Microbiol Biotechnol 11, 26-57.

Slobodkin, A. I. \& Bonch-Osmolovskaya, E. A. (1994). Growth and formation of metabolic products by extremely thermophilic archaea of the genus Desulfurococcus in the presence and absence of elemental sulfur. Microbiology (English translation of Mikrobiologiia) 63, 552-554.

Stetter, K. O. (1986). Diversity of extremely thermophilic archaebacteria. In Thermophiles: General, Molecular and Applied Microbiology, pp. 39-74. Edited by T. D. Brock. New York: Wiley.

Stetter, K. O. (1996). Hyperthermophilic procaryotes. FEMS Microbiol Rev 18, 149-158.

Thompson, J. D., Higgins, D. G. \& Gibson, T. J. (1994). CLUSTAL W: improving the sensitivity of progressive multiple sequence alignment through sequence weighting, position-specific gap penalties and weight matrix choice. Nucleic Acids Res 22, 4673-4680.

Tourova, T. P., Kuznetsov, B. B., Kalganova, T. B. \& BonchOsmolovskaya, E. A. (2000). Phylogenetic position of Desulfurococcus amylolyticus. Microbiology (English translation of Mikrobiologiia) 69, 369-370.

Van de Peer, Y. \& De Wachter, R. (1994). TREECON for Windows: a software package for the construction and drawing of evolutionary trees for the Microsoft Windows environment. Comput Appl Biosci 10, 569-570.

Wolin, E. A., Wolin, M. J. \& Wolfe, R. S. (1963). Formation of methane by bacterial extracts. J Biol Chem 238, 2882-2888.

Zillig, W., Stetter, K. O., Prangishvilli, D., Schaefer, W., Wunderl, S., Janekovic, D., Holz, I. \& Palm, P. (1982). Desulfurococcaceae, the second family of the extremely thermophilic, anaerobic, sulfurrespiring Thermoproteales. Zentralbl Bakteriol Parasitenkd Infektionskr Hyg Abt 1 Orig C3, 304-317.

Zillig, W., Holz, I., Klenk, H.-P., Trent, J., Wunderl, S., Janekovic, D., Imsel, E. \& Haas, B. (1987). Pyrococcus woesei, sp. nov., an ultrathermophilic marine Archaebacterium, representing a novel order, Thermococcales. Syst Appl Microbiol 9, 62-70. 